DOI: https://doi.org/10.47405/mjssh.v6i5.795

\begin{tabular}{|c|c|}
\hline $\begin{array}{c}\text { Malaysian Journal of } \\
\text { socilisciences and } \\
\text { Humanities } \\
\text { (MJ - SSH) }\end{array}$ & Malaysian Journal of Social Sciences and Humanities (MJSSH) \\
& Volume 6, Issue 5, May 2021 \\
\hline & e-ISSN : 2504-8562 \\
& Journal home page: \\
& www.msocialsciences.com \\
\hline
\end{tabular}

\title{
Pengukuhan Orientasi Seksual Terhadap Sesama Jenis (Gay) dalam kalangan Remaja Lelaki: Implikasi Terhadap Keluarga dan Rakan Sebaya
}

\author{
Abdul Rashid Abdul Aziz¹, Rezki Perdani Sawai' ${ }^{1}$, Mohamad Isa Amat ${ }^{1}$, Norsuhaida Che Musa², Joki \\ Perdani Sawai $^{3}$ \\ ${ }^{1}$ Fakulti Kepimpinan dan Pengurusan, Universiti Sains Islam Malaysia (USIM) \\ ${ }^{2}$ Fakulti Syariah dan Undang-undang, Universiti Sains Islam Malaysia (USIM) \\ 3Universiti Malaysia Sabah (UMS) \\ Correspondence: Abdul Rashid Abdul Aziz (ashid@usim.edu.my)
}

\begin{abstract}
Abstrak
Masalah homoseksual di seluruh dunia kian membimbangkan dan Malaysia turut tidak terlepas dari terkena tempias amalan songsang ini. Tambah merunsingkan adalah apabila perangkaan statistik menunjukkan peningkatan trend individu yang mengamalkan homoseksual (gay) ini. Sesungguhnya orientasi seksual terhadap sesama jenis ini mempunyai pelbagai implikasi negatif kepada pengamalnya dan individu di sekeliling mereka seperti ibu bapa dan rakan sebaya. Justeru, kajian ini dijalankan adalah untuk mengenal pasti faktor pengukuhan orientasi seksual terhadap sesama jenis (gay) dalam kalangan remaja lelaki serta implikasinya terhadap keluarga dan rakan sebaya. Maklumat yang diketengahkan adalah berdasarkan kajian kualitatif melalui reka bentuk kajian skop. Sebanyak 36 artikel telah dijumpai dan dipilih dari EBSCO-Host, pangkalan data universiti bermula dari tahun 2015 hingga Januari 2021. Melalui teori pengukuhan atau pembentukan identiti gay yang dikemukakan oleh Cass (1996), pemahaman terhadap pengukuhan orientasi seksual terhadap sesama jenis dalam kalangan remaja dapat dihuraikan secara terperinci. Kajian mendapati bahawa terdapat pelbagai faktor yang membawa kepada pengukuhan orientasi seksual terhadap gay termasuklah faktor genetik, gaya asuhan ibu bapa, naluri dan faktor persekitaran. Orientasi seksual terhadap sesama jenis ini juga telah memberikan pelbagai implikasi negatif kepada perhubungan antara ibu bapa dan rakan sebaya. Konklusinya, kajian ini amatlah relevan dan signifikan dalam membincangkan isu homoseksual kerana ia dapat membantu badan-badan terlibat termasuklah keluarga dan rakan sebaya dalam mengatur strategi-strategi terpilih bagi berhadapan dengan implikasi buruk dari amalan homoseksual ini.
\end{abstract}

Kata kunci: orientasi seksual, gay, homoseksual, hubungan seks antara lelaki

\section{Sexual Orientation Reinforcement Towards Same -Sex (Gay) among Male Adolescents: Implications for Family and Peers}

\begin{abstract}
The problem of homosexuality around the world is becoming more and more worrying. Malaysia also included to the temptation of this perverse practice. Adding to the concern, statistics showed an increasing trend of individuals practicing homosexuality (gay). Indeed, sexual orientation towards similar sex has various negative implications for its practitioners and individuals around them such as parents and peers. Thus, this study was conducted to identify the factors involves in sexual orientation
\end{abstract}


reinforcement towards the same sex (gay) among male adolescent and its implications for family and peers. The information presented is based on a qualitative study through scoping review study design. A total of 36 articles were found and selected from EBSCO-Host, a university database from 2015 to January 2021. Through the theory of reinforcement or formation of gay identity by Cass (1996), an understanding of the same-sex sexual orientation reinforcement among adolescents can be described in detail. The study found that there are various factors that lead to the strengthening of sexual orientation towards gays including genetic factors, parenting style, instincts and environmental factors. Sexual orientation towards similar sex also had various negative implications on the relationship between parents and peers. In conclusion, this study is very relevant and significant in discussing the issue of homosexuality because it can help the bodies involved including family and peers in organizing selected strategies to deal with the adverse implications of this homosexual practice.

Keywords: sexual orientation, gay, homosexual, men sex with man (MSM)

\section{Pengenalan}

Setiap manusia pasti akan melalui zaman remaja. Zaman remaja sering diistilahkan sebagai zaman perantaraan di antara zaman kanak-kanak dan zaman dewasa. Zaman remaja juga merupakan detik permulaan kepada pembinaan identiti dan personaliti diri. Maka, pada peringkat ini, para remaja melalui proses mencari identiti masing-masing sehingga menimbulkan pelbagai persoalan dan kecelaruan dalam diri mereka, rentetan dari pembinaan identiti tersebut. Orientasi seksual merupakan antara persoalan utama yang sering dikaitkan dengan remaja. Hal ini kerana, zaman remaja sinonim dengan proses pembinaan dan pembentukan orientasi seksual remaja melalui pemilihan, kecenderungan dan rangsangan terhadap kehendak seksual masing-masing.

Isu seksual sering dianggap sebagai persoalan yang hangat dan menjadi polemik dalam masyarakat. Realitinya, masyarakat sedang berhadapan dengan bahaya dan ancaman baharu disebabkan perkembangan gejala seksual yang tidak sihat, sehingga menggugat integriti sosial dan masyarakat. Peranan keluarga dan ibu bapa pada dekad ini juga lebih mencabar khususnya dari segi menangani masalah dan gejala seksual yang membabitkan ahli keluarga, termasuklah anak kecil dan remaja. Gejala dan isu seksual yang kritikal mencabar serta memberi kesan yang buruk kepada masa depan masyarakat dan negara (Rezki et al., 2019). Isu ini telah menjadi perhatian, perbincangan, isu dan telah dikupas dalam Seminar Seksual Kebangsaan pada tahun 2005 yang telah diadakan di Universiti Malaya (UM). Salah satu isu seksual yang diberi perhatian serius dalam seminar tersebut adalah isu homoseksualiti.

Homoseksual merujuk kepada tingkah laku seks yang ditujukan kepada perhubungan seks sama jantina. Gay biasanya menerangkan perhubungan seks antara lelaki dengan lelaki. Lesbian digunakan bagi menerangkan perhubungan seks antara perempuan dengan perempuan. Di Malaysia, gejala homoseksual telah menjadi satu trend atau gaya hidup golongan remaja. Antara faktor yang menyebabkan berleluasanya gejala homoseksual adalah perubahan cara hidup dan cara berfikir dalam masyarakat yang kian moden (Suriati et al., 2012), pengaruh media massa, isu penguatkuasaan undang-undang yang samar berkaitan gerakan Lesbian, Gay, Biseksual dan Transgender (LGBT) (Mohamad Afandi \& Mohd Sabree, 2019), pengaruh rakan sebaya dan juga persekitaran keluarga yang feminin (Azlina \& Hashimi, 2019). Di samping itu, perubahan sosial yang berlaku dalam masyarakat seperti terdapatnya kemudahan yang disediakan dalam komuniti seperti kafe siber, dan juga kemudahan tandas yang dianggap sebagai satu sistem sokongan kepada mereka (Suriati et al., 2009). Aplikasi gay yang boleh dimuat turun melalui perisian Google Play Store seperti 'Hornet', dan 'Grindr' yang diwujudkan khas bagi golongan gay memburukkan lagi keadaan. Kesemua faktor ini menyumbang kepada pengukuhan gaya hidup golongan ini.

Walau bagaimanapun, gaya hidup yang dipilih oleh golongan minoriti ini tidak seindah yang mereka bayangkan. Gaya hidup ini memberi pelbagai kesan negatif kepada individu dan masyarakat. Penganiayaan rakan sebaya adalah salah satu penyebab utama tingkah laku seksual berisiko tinggi dalam 
kalangan pelajar sekolah rendah dan menengah. Remaja LGBT sering dibuli, bertengkar, terlibat dalam masalah ponteng sekolah, dan bergelut dengan tekanan emosi dan masalah buli. Malah, remaja gay lebih cenderung menjadi mangsa buli dari remaja heteroseksual. Tambahan pula, gangguan verbal dan fizikal bersama dengan faktor lain seperti penggunaan bahan dan penolakan keluarga boleh menyebabkan peningkatan risiko untuk idea bunuh diri (suicidal ideation). Justeru, artikel ini membincangkan fenomena homoseksualiti rentetan faktor persekitaran dan perubahan sosial dalam masyarakat yang menyokong kepada pengukuhan orientasi seksual golongan ini. Artikel ini juga merungkai tentang peranan ibu bapa dan rakan sebaya dalam membantu remaja lelaki gay untuk kembali ke pangkal jalan dan mengelakkan mereka dari terlibat dalam pelbagai masalah sosial seperti kecenderungan untuk membunuh diri, penyalahgunaan bahan dan pelacuran.

\section{Sorotan Literatur}

Di dalam melayari kehidupan sebagai seorang remaja, pelbagai anasir dan permasalahan yang dilihat dapat mengganggu-gugat jiwa dan perasaan golongan remaja yang akhirnya membawa kepada tekanan yang lebih besar dalam hidup mereka. Orientasi seksual merupakan fasa penting yang di alami remaja dalam mengenali keperluan seksual dan pemilihan pasangan mereka. Namun, orientasi seksual juga sering mengundang permasalahan. Hal ini kerana, mereka yang mempunyai kecenderungan seksual yang songsang atau berbeza dari orientasi seksual normal sering menyalahkan keadaan dan diri mereka melalui persepsi negatif yang terbina dalam diri mereka dalam menginterpretasikan persepsi masyarakat terhadap mereka. Permasalahan yang tidak dibendung atau diatasi segera akan membawa kepada gejala sosial yang lebih kronik seperti pelacuran, seks bebas, membunuh diri, lari dari rumah, dan banyak lagi.

Orientasi seksual adalah asas kepada seksualiti manusia yang merujuk kepada tarikan seksual sama ada terhadap lelaki atau wanita yang ditunjukkan melalui kepelbagaian seks (Rahman \& Wilson, 2003). Terdapat banyak istilah yang digunakan bagi menerangkan maksud orientasi seksual, namun begitu penerangan awal telah dilakukan lebih dari 130 tahun yang lalu (Ulrichs, 1994; Sell, 1997). Definisi umum orientasi seksual bertumpu kepada konsep 'orientasi' iaitu kecenderungan erotik terhadap sesuatu jantina atau lebih, dan kebiasaannya digambarkan sebagai tarikan seksual atau tarikan erotik (SavinWilliams \& Ream, 2007; Sell, 1997). Dalam membincangkan dan mengupas tajuk orientasi seksual remaja, elemen penting yang menjadi persoalan adalah pemilihan atau kecenderungan seksual remaja, sama ada yang berorientasikan sesama jenis (homoseksual), berlainan jenis (heteroseksual), dan keduaduanya (biseksual). Namun demikian, dalam melayari zaman remaja yang juga dikenali sebagai zaman transisi sementara ini, para remaja boleh mengalami "kebingungan" atau ketidakpastian terhadap orientasi seksual mereka. Misalnya, seorang remaja lelaki yang mempunyai kecenderungan seksual berlainan jenis (heteroseksual), masih melakukan hubungan sesama jenis (homoseksual), disebabkan oleh pengaruh persekitaran, rakan sebaya dan juga pengamalan gaya hidup yang bebas (Coleman, 1995).

Homoseksual berlaku di semua lapisan masyarakat di dunia dengan dianggarkan 21 peratus lelaki di dunia menjadi gay (Beren, 2013). Jabatan Kemajuan Islam Malaysia (JAKIM), melaporkan peningkatan gay hampir 100 peratus iaitu sebanyak 310,000 orang pada 2018 berbanding 173,000 orang pada 2017 (Berita Harian, 2018). Menurut Kamal Azmi et al (2015), masyarakat Melayu menyumbang peratusan kedua tertinggi (19 peratus) berbanding orang Cina ( 70 peratus). Peningkatan ini bukan sahaja meningkat dari segi jumlah tetapi juga peningkatan pesakit HIV yang berkaitan dengan lelaki yang melakukan hubungan seks dengan lelaki (Global AIDS Response Progress Report, 2016). Manakala, berdasarkan laporan tinjauan iaitu Youth Risk Behavior Survey (YRBS) pada tahun 2016 di Amerika Syarikat pula mendapati bahawa 34 peratus remaja LGBT dibuli di sekolah, 18 peratus menyatakan melakukan seks secara dipaksa, 23 peratus adalah mangsa keganasan seksual, dan 18 peratus berjuang menghadapi kekerasan fizikal. Tinjauan ini dijalankan di 10 buah negeri dan 10 buah daerah dari sekolah kawasan bandar yang mendedahkan bahawa pelajar minoriti seksual seperti LGBT berisiko lebih besar untuk diganggu, dicederakan dengan senjata dan dibuli oleh pelajar heteroseksual (Hafeez et al., 2017).

Di Malaysia, kajian kualitatif yang dijalankan oleh Amran dan Amat (2015) yang membabitkan sebanyak lapan orang responden kajian iaitu terdiri dari empat orang lelaki dan empat orang perempuan dari golongan profesional yang berumur di antara 29 hingga 53 tahun. Responden berpendapat bahawa 
golongan homoseksual merupakan golongan transeksual atau lelaki lembut yang mempunyai sikap lebih teliti, rapi, pandai menjaga penampilan diri, bersifat keperempuanan dan mudah beremosi. Hal ini dijelaskan oleh Syarifah (2011) yang menyatakan golongan ini menghadapi kecelaruan yang melibatkan orientasi seksual sama ada berkait rapat dengan faktor keluarga, biologi, persekitaran, media dan sejarah penderaan semasa kecil. Namun, apa yang harus difahami ialah golongan transeksual tidak semestinya homoseksual, dan golongan homoseksual boleh terdiri daripada sesiapa sahaja termasuk lelaki yang tegap dan sasa (Amran et al., 2015; Syarifah, 2011). Menurut Amran dan Amat (2015) pengukuran yang dinyatakan ini bukanlah pengukuran yang hakiki dan tepat disebabkan aspek fizikal bukanlah melambangkan diri seseorang yang sebenar. Bahkan asas kepada kefahaman psikologi juga menumpukan kepada pemahaman jiwa.

Selain itu, kajian kualitatif yang menggunakan reka bentuk fenomenologi telah dijalankan oleh Fadzilah dan Noremy (2019) bagi mengenal pasti faktor yang mengundang kepada berlakunya kecenderungan menjadi golongan LGBT. Kajian dilakukan menggunakan kaedah temu bual secara mendalam dengan melibatkan tujuh orang responden yang terdiri daripada mahasiswa IPTA dengan menggunakan teknik pensampelan bola salji (snow ball). Hasil dapatan kajian mendapati terdapat pelbagai faktor penglibatan golongan LGBT. Hal ini adalah berpunca dari cetusan faktor personaliti semula jadi, pengaruh persekitaran sosial, sokongan sosial berbentuk material, berpengalaman menghadapi gangguan seksual, tidak mendapat kasih sayang yang secukupnya, memperoleh sokongan dari ahli keluarga, mempunyai rangsangan seksual, keinginan dan kepuasan seksual, sentiasa didatangi rasa kesunyian, terpengaruh dengan rakan sejenis dan keinginan orientasi seksual. Kesemua faktor ini mengundang kepada penglibatan dalam dunia LGBT dan menggalakkan perkara ini berleluasa di kalangan golongan muda penuntut IPTA.

Radclyffe (1928) dalam karyanya yang bertajuk 'The Well of Loneliness' berpandangan bahawa dalam kajian mengenai gay dan lesbian, terdapat beberapa aspek yang memerlukan pemahaman mendalam. Permasalahan yang wujud pada remaja yang mengalami kecelaruan seksual ini adalah kerana remaja terbelenggu dengan perasaan serba salah serta masih tercari-cari identiti mereka yang sebenar. Dalam erti kata mudah, remaja ini sebenarnya mengalami gangguan terhadap kekeliruan identiti mereka yang dilihat berlainan orientasi dari keadaan normal yang biasa. Secara umumnya, terdapat tiga tahap perkembangan yang berkaitan dengan gaya hidup gay yang perlu diamati dan dikaji. Tiga fokus pengkajian membabitkan permasalahan dalam perkembangan seks remaja gay adalah meliputi pemahaman mengenai;
i. Perkembangan dan pemantapan dalam pembentukan identiti seksual
ii. Maklum balas ibu bapa
iii. Hubungan sesama rakan sebaya

Menurut teori psikososial yang dikemukakan oleh ahli psikologi iaitu Erikson (1963), bahawa dalam memahami perspektif psikososial remaja, maka hubungan antara pembesaran remaja dan juga keadaan sosial adalah berkait rapat di dalam membentuk perkembangan atau penolakan dalam diri seseorang remaja. Ia membentuk tingkah laku serta memberikan impak besar di dalam mempengaruhi gaya hidup remaja itu sendiri (Gullotta et al., 2000). Erikson (1963) juga menyatakan bahawa persoalan mengenai pembinaan identiti, keyakinan diri serta kemahiran sosial adalah elemen utama kepada seseorang manusia yang perlu dipenuhi dari sudut psikologinya. Permasalahan untuk mencapai tahap kesempurnaan ini ada kalanya dilihat sukar dicapai oleh masyarakat gay, terutamanya pada tahap remaja. Schneider (1989) pula berpandangan bahawa remaja gay ini mempunyai dua permasalahan utama iaitu di dalam memperkenalkan diri sebagai homoseksual dan juga masalah dalam perkembangan diri dalam proses tumbesaran manusia. Teori kawalan sosial (social-control theory) menyebutkan bahawa secara kebiasaannya, pengaruh utama yang membentuk perlakuan adalah berkait rapat dengan pengaruh ibu bapa, kebudayaan dan juga media (Gullotta et al., 2000). 


\section{Metod Kajian}

Kajian ini merupakan kajian kualitatif dengan menggunakan reka bentuk kajian skop atau scoping review. Analisis kajian skop melibatkan proses yang dirancang untuk menyatukan data mentah ke dalam kategori atau tema berdasarkan kesimpulan dan tafsiran yang sah. Proses ini menggunakan penaakulan induktif, di mana tema dan kategori muncul dari data melalui pemeriksaan teliti dan perbandingan berterusan penyelidik. Tetapi reka bentuk kajian skop tidak perlu mengecualikan penaakulan deduktif (Patton, 2002). Menjana konsep atau pemboleh ubah dari teori atau kajian terdahulu juga sangat berguna untuk kualitatif penyelidikan, terutamanya pada permulaan analisis data (Berg, 2001).

Pendekatan kajian skop ini adalah berdasarkan 5 kerangka analisa daripada Arksey dan O'Malley's (2005) yang terdiri daripada 6 langkah iaitu; (1) mengenal pasti persoalan kajian, (2) mengenal pasti kajian yang relevan, (3) pemilihan kajian, (4) memetakan data, dan (5) menyusun, meringkaskan dan melaporkan hasil berdasarkan tema dan kategori kajian, dan akhir sekali (6) menjalankan konsultasi - di peringkat ini, pemegang taruh dijemput oleh penyelidik untuk memberikan pandangan dan maklum balas tentang celik akal hasil daripada data serta mengesahkan data tersebut dari perspektif pendekatan kajian skop (Scharew \& Macaluso, 2019). Tujuan utama adalah untuk mengenal pasti tema atau kategori penting dalam kajian skop untuk memberikan gambaran yang kaya tentang realiti sosial yang dibuat oleh tema/ kategori.

Dalam kajian ini, artikel daripada sumber dari jurnal, majalah, surat khabar, buletin yang menumpukan kepada isu pengukuhan orientasi seksual terhadap hubungan sesama jenis (Gay) dalam kalangan remaja lelaki serta implikasinya terhadap keluarga dan rakan sebaya telah dipilih untuk dianalisis. Artikel-artikel terpilih diperoleh daripada pangkalan data universiti iaitu Academic Search Premier@EBSCOhost yang diterbitkan bermula dari tahun 2015 hingga Januari 2021. Sebanyak 36 artikel telah dijumpai dan dipilih dari EBSCO-Host. Malah artikel yang relevan dan signifikan dari tahun sebelumnya juga diambil kira. Pengkaji menggunakan kata kunci yang berikut iaitu. Selain itu, pengkaji juga mengenal pasti kata atau frasa lain yang muncul seperti orientasi seksual, gay, homoseksual, dan hubungan seks antara lelaki (men sex with men, MSM) dan menganalisis makna di sebalik setiap satu konsep untuk lebih memahami isu yang dibincangkan. Hanya artikel yang berbentuk akademik dan mempunyai rujukan serta artikel yang telah dinilai oleh pengkaji lain secara ilmiah dipilih dalam kajian ini. Bagi memastikan kebolehpercayaan dan kredibiliti hasil kajian, pengkaji menilai data yang diperoleh dengan mengenal pasti sama ada terdapat persamaan dalam dan perbezaan antara kategori yang terhasil. Artikel yang berbentuk prosiding, tidak lengkap, tidak boleh dimuat turun dan tidak berkaitan dengan skop kajian tidak akan dipilih. Ini dilakukan dengan membaca, menganalisis dan menstrukturkan kandungan yang relevan mengikut topik kajian literatur. Seterusnya, hubung kait antara cadangan atau topik kajian literatur dengan penyelidikan terdahulu dilakukan. Kemudian, artikel pilihan kemudian dianalisis dan dikategorikan mengikut skop kajian bagi mendapatkan pemahaman yang lebih, mengenai isu berkaitan pengukuhan orientasi seksual terhadap hubungan sesama jenis (gay) dalam kalangan remaja.

\section{Hasil Kajian \& Perbincangan}

\section{Proses Pengukuhan Orientasi seksual lelaki (gay)}

Pada dasarnya, rata-rata remaja pada masa kini sinonim dengan perkataan homoseksual dan kewujudan golongan tersebut di dalam masyarakat khususnya, dan dunia amnya. Menurut Anderson (1987), kesedaran remaja terhadap orientasi seksual mereka yang tertarik kepada hubungan sesama jenis (gay), telah muncul seawal remaja mencapai umur antara 12 hingga 14 tahun. Pada ketika ini juga, mereka menyedari bahawa perbuatan atau tingkah laku homoseksual membawa konotasi negatif atau tercela di sisi masyarakat serta membawa pengertian gaya hidup yang salah dan songsang. Namun proses pengukuhan untuk menjadi lelaki gay menjadikan mereka berusaha ke arah mencapai satu identiti gay yang positif melalui penyesuaian diri, berbanding daripada mendapat cemuhan dan pandangan negatif masyarakat. 
Terdapat pelbagai faktor seperti pola dan gaya asuhan keibubapaan, naluri, biologi, dan persekitaran yang mendorong remaja ke arah pengukuhan orientasi dan budaya homoseksual. Malah, terdapat pelbagai perselisihan pendapat berhubung punca terjadinya dorongan orientasi gay iaitu faktor genetik serta persekitaran. Perbahasan juga timbul mengenai sama ada orientasi gay berlaku secara semula jadi atau satu pilihan yang dibuat individu untuk menjadi gay. Walau bagaimanapun, faktor pendorong dan tarikan ini menjadi salah satu fokus utama untuk mendapatkan jawapan tentang pengukuhan orientasi gay. Faktor tarikan (pull factor) merujuk kepada faktor yang mendorong seseorang menjadi Gay. Faktor ini menyatakan bahawa tarikan nafsu, rasa seronok melakukan hubungan songsang dan kesenangan. Faktor tarikan ini dapat dilabelkan sebagai kehendak diri. Kehendak diri sendiri menjadi faktor tarikan pengukuhan orientasi menjadi gay kerana mereka merasa lebih selesa untuk mengikut kehendak diri sendiri. Dalam tema kehendak diri ini, terdapat beberapa sub-tema yang membawa kepada kehendak diri, iaitu naluri, nafsu dan perasaan senang (pleasure) ketika bersama lelaki (Clare et al., 2016).

Selain itu, di antara tokoh awal yang mengemukakan teori pengukuhan atau pembentukan identiti gay ini adalah Cass (1996). Dalam model beliau, Cass (1996) menyatakan pembentukan dan pengukuhan identiti gay melalui enam tahap (six-stage). Tahap yang pertama adalah kesedaran diri atau identiti. Kesedaran ini merujuk kepada tahap kesedaran individu gay bahawa mereka berbeza dari orang lain. Tahap kedua ialah, perbandingan identiti di mana individu gay yang merasakan kemungkinan untuk menjadi homoseksual, tidak merasa bimbang untuk terus menjadi homoseksual dan tidak bertingkah laku seperti lelaki normal (heteroseksual) walaupun mengetahui wujud perbezaan identiti di antara kedua-dua orientasi seksual tersebut. Tahap ketiga ialah toleransi identiti yang menyatakan bahawa individu merasakan orientasi seksual yang terbit dalam dirinya sebagai satu sumpahan, namun secara peribadinya mereka masih menerima orientasi seksual tersebut. Tahap keempat ialah penerimaan identiti, iaitu individu secara selektif keluar dari kepompong mereka dan mula bercampur-gaul dengan komuniti gay. Tahap kelima adalah kebanggaan identiti, yang menyatakan bahawa pada tahap ini, individu telah mempunyai penerimaan ke atas diri sendiri dan terlibat dengan komuniti gay. Terdapat segelintir daripada mereka yang berada di tahap ini mendiskriminasikan golongan heteroseksual. Tahap keenam pula ialah sintesis, iaitu individu telah berupaya untuk menerima dirinya dan orang lain (heteroseksual) dan perbezaan yang wujud bukan menjadi suatu masalah atau konflik lagi. Kesemua tahap ini menggambarkan proses pengukuhan dan pembentukan orientasi seksual remaja walaupun tidak dinyatakan secara spesifik jangka masa umur individu yang melalui tahap-tahap tersebut.

Identiti gay tidak muncul serta-merta dan diterima begitu sahaja oleh seorang individu. Identiti tersebut muncul melalui tahap-tahap perkembangan identiti homoseksual. Hal ini berkait dengan proses seseorang menjadi gay. Individu mungkin akan melalui setiap peringkat, kekal pada tahap tertentu, atau menamatkan pergerakan ke peringkat lain dalam proses pembentukan identiti homoseksual (Cass, 1996). Zuraidah et al. (2018) menyatakan bahawa antara faktor-faktor yang menyumbang kepada percanggahan identiti gender ialah pemikiran dan norma dominan sesuatu masyarakat terhadap sempadan gender. Individu yang tidak dapat mengidentifikasikan dirinya dalam mana-mana kelompok genital dianggap mengalami masalah kecelaruan sistem gender. Malah terdapat lagi kajian yang menyokong faktor genetik yang membawa kepada penglibatan individu dalam kancah gay (Ahmad, 2016).

\section{Hubungan dengan Rakan sebaya}

Terdapat remaja lelaki gay yang tidak terlibat dalam sebarang aktiviti di sekolah dan memilih untuk tidak menjalinkan persahabatan dengan rakan sebaya yang sama jenis (lelaki). Ini disebabkan oleh perasaan takut terbongkarnya identiti atau orientasi seksual mereka dan merasakan bahawa mereka tidak dapat berkongsi masalah yang dihadapi dengan rakan sebaya mereka (Casey, 2015). Natijahnya, remaja ini akan meminggirkan diri mereka ataupun dipinggirkan oleh rakan sebaya. Selain itu, mereka juga dilihat lebih gemar untuk berjumpa dan berkawan dengan remaja-remaja yang berlainan jantina (perempuan) sebagai satu cara untuk menyesuaikan diri dengan rakan sebaya. Remaja lelaki gay juga sukar untuk mengadaptasikan diri mereka, atau bercampur-gaul dengan budaya dan kelompok lelaki gay dewasa. Ini adalah kerana kelompok lelaki gay dewasa lebih gemar dan cenderung kepada aktiviti golongan dewasa. Mereka juga mengasingkan penglibatan mereka dengan lelaki gay remaja kerana mereka khuatir berkemungkinan didakwa atas kesalahan mempromosikan budaya homoseksual ataupun menggoda golongan remaja. 
Selain itu, remaja lelaki berisiko untuk menjadi gay sekiranya rakan sebaya yang mengajak dan mengajar mereka mengenai kehidupan sebagai seorang gay. Remaja mudah dipengaruhi oleh rakan sebaya melalui aspek populariti, keinginan untuk diterima oleh rakan sebaya dan tekanan dari rakan sebaya. Oleh itu, amat penting bagi ibu bapa mendidik anak-anak sejak kecil tentang kepentingan memilih sahabat yang baik dari segi akhlaknya yang selari dengan ajaran Islam. Menurut Azmin dan Muhamad Ismail (2017), sahabat yang baik boleh mendorong seseorang untuk melakukan kebaikan sama ada melalui nasihat yang baik, tunjuk ajar yang berkesan, serta teladan yang boleh dicontohi. Masyarakat akan mempunyai tanggapan yang buruk terhadap seseorang sekiranya bersahabat dengan orang yang jahat kerana persepsi umum bahawa berpotensi untuk dipengaruhi menjadi jahat. Oleh itu, sekiranya remaja gay ini terlibat dalam kancah perbuatan yang terlarang sejak remaja, ia sedikit sebanyak adalah pengaruh dari rakan sebaya yang mempunyai kecenderungan yang sama.

Dalam budaya di Malaysia, gay adalah suatu amalan atau gaya hidup yang tidak akan diterima sama sekali (Nina, 2019). Walaupun Malaysia adalah negara yang mengamalkan dasar pemerintahan demokrasi, namun ia bukanlah satu tiket untuk membenarkan golongan gay untuk melakukan aktiviti mereka. Penerimaan sosial terhadap golongan homoseksual (gay) di Malaysia masih terbatas kerana dasar yang diamalkan oleh kerajaan masih berlandaskan kepada garis panduan yang ditetapkan dalam Islam yang merupakan agama rasmi di Malaysia yang melarang sama sekali golongan ini (Mahfudzah, 2015). Hal ini telah mewujudkan unsur stigma dalam amalan gay, gay related stigma (Johnson et al., 2008). Hal ini telah mewujudkan jurang dalam perhubungan dengan rakan sebaya. Kajian yang dijalankan oleh Azlina et al. (2019) mendapati bahawa sekiranya amalan gay individu diketahui oleh rakan di sekeliling, individu tersebut akan mendapat cemuhan dan dipinggirkan oleh rakan-rakan. Hal ini seterusnya menimbulkan keresahan dalam individu yang mengamalkan gay. Selain itu, individu turut berasa kesunyian apabila tidak bergaul sesama rakan-rakan. Menurut Proctor dan Groze (1994), golongan gay sentiasa berhadapan dengan diskriminasi, pengasingan, dan kesepian yang berpunca daripada faktor penolakan masyarakat.

\section{Maklum balas Ibu bapa}

Hakikatnya, remaja lelaki gay sering berasa takut untuk mendedahkan orientasi seksual mereka kepada ibu dan bapa kerana mereka beranggapan dan menjangkakan timbulnya maklum balas negatif seperti marah, terperanjat dan kecewa di pihak ibu dan bapa mereka. Walaupun perkongsian masalah di antara remaja dengan ibu dan bapa merupakan medium utama dalam menangani sebarang masalah yang dihadapi remaja, namun tindak balas dari ibu dan bapa tidak dapat di ramalkan. Hal ini kerana, ibu dan bapa berkemungkinan menerima atau menolak perkhabaran yang diterima dari anak mereka. Misalnya, ibu dan bapa berkemungkinan untuk memaksa anak mereka kembali kepada fitrah asal atau memarahi anak mereka setelah mengetahui anak mereka mempunyai kecenderungan seksual terhadap sesama jenis atau homoseksual. Dorongan perasaan takut dan bimbang ini, akhirnya menyebabkan remaja lelaki gay terus memendam permasalahan yang di hadapi.

Menurut Lilybeth et al. (2014), menerusi kajian yang telah dijalankan juga menunjukkan, sebilangan ibu bapa yang tidak dapat menerima perkhabaran berkenaan pemilihan orientasi seksual yang 'songsang' seperti homoseksual. Mereka bertindak untuk menyisihkan anak atau menyingkirkan mereka dari rumah, serta berlakunya penderaan fizikal dan mental ke atas anak mereka. Kristinn dan Lars (2007) kesan daripada penyisihan yang dilakukan keluarga, remaja gay dilihat lebih berpotensi terlibat dalam gejala bunuh diri berbanding dengan remaja heteroseksual. Kajian juga memperlihatkan bahawa kebanyakan remaja lelaki yang terlibat dengan kegiatan gay, apabila disisihkan keluarga telah menyebabkan ramai di antara mereka yang terjebak ke lembah pelacuran. Pelacuran menjadi antara gejala sosial yang timbul rentetan daripada ketidakpekaan ibu bapa di dalam memahami dan membantu anak-anak mereka menempuhi alam remaja khususnya bagi menangani isu homoseksualiti ini.

Ibu bapa juga perlulah mendedahkan kepada remaja mengenai pendidikan seks dan juga bersikap terbuka mengenainya (Coleman, 1995). Roseliza (2013) menekankan bahawa ibu bapa dan keluarga menjadi faktor utama kepada penglibatan anak-anak ke dalam gejala gay ini. Menurut Coleman (1995), perkara yang amat sukar yang perlu dilalui remaja gay adalah untuk berkongsi masalah seks serta memberitahu 
orientasi seks mereka kepada ibu bapa. Untuk itu, bagi mengelakkan sebarang masalah yang lebih rumit membabitkan anak-anak di bawah jagaan mereka, ibu bapa sepatutnya bersikap lebih terbuka dan celik ilmu terhadap segala keperluan anak remaja yang membesar dan aspek psikologi mereka. Ibu bapa juga perlu berusaha untuk memahami masalah remaja secara lebih konstruktif agar remaja dapat merasakan kehadiran ibu bapa dalam kehidupannya.

Selain itu, terdapat juga sebilangan ibu bapa yang lebih terbuka dan dapat menerima perkhabaran tentang keterlibatan anak mereka dalam isu homoseksualiti dengan lebih positif. Hal ini akan mempermudah proses bantuan yang boleh disalurkan kepada anak-anak. Hal ini kerana, ibu dan bapa boleh berperanan sebagai pembakar semangat dan pendorong ke arah perubahan yang positif bagi anak melalui bimbingan yang berterusan. Ibu dan bapa juga boleh berkongsi pengalaman dan ilmu pengetahuan tentang bahaya pengamalan budaya homoseksual dan penerapan tersebut dapat dilakukan kepada anak lebih awal sebelum permasalahan menjadi kian kronik.

\section{Kesimpulan}

Kesimpulannya, mendepani modenisasi dan revolusi industri 4.0 membawa pelbagai cabaran dan norma baharu yang harus diadaptasi sebaiknya. Umumnya, isu homoseksualiti menjadi suatu fenomena sosial yang lazim di seluruh dunia bahkan di Malaysia juga isu ini kian meruncing. Homoseksualiti didedahkan secara ketara oleh media sebagai suatu gejala sosial yang lahir daripada kebejatan sosial. Namun begitu, golongan dilihat semakin berani dan ketara dalam menonjolkan diri mereka di platform media sosial sekali gus memberi petunjuk yang membimbangkan dalam peningkatan kadar isu sosial. Ajaran Islam melarang perbuatan dan gejala homoseksual (gay) secara jelas di dalam Al-Quran. Hal ini adalah demi menjaga dan memelihara manusia dan tamadun manusia daripada kerosakan. Justeru, bagi menangani permasalahan ini, ibu dan bapa, keluarga serta rakan sebaya dilihat sebagai agen utama yang dapat meneutralkan tekanan yang di alami dan membantu usaha pemulihan remaja melalui sokongan psikososial yang padu, penerimaan tanpa syarat dan bimbingan yang berterusan.

\section{Rujukan}

Ahmad Tarmizi Muhammad. (2016). Kes Kekeliruan Gender (Khuntha): Analisis dari Perspektif Islam dan Perubatan. Jurnal Penyelidikan Islam. No 27, Wilayah Persekutuan: JAKIM.

Amran, H. \& Salleh, A. (2015). Kefahaman terhadap aspek pendefinisian dan ciri utama golongan homoseksual. e-Bangi: Journal of Social Science and Humanities, 10(1), 195-207.

Azmin, Yusof \& Muhamad Ismail, Abdullah. (2017). Adab Unggul Islam dalam Persahabatan antara Insan. Malaysian Online Journal of Education, 1(2), 102-112.

Azlina Mohd Khir \& Che W Hashimi Rafsanjani Che W Raksan. (2019). Faktor Keterlibatan Belia Dalam Isu Gay di Kuala Lumpur. Institut Penyelidikan Pembangunan Belia Malaysia. 145-159.

Azlina Mohd Khir, Che W Hashimi Rafsanjani Che W Raksan, Aini Azeqa Ma'rof \& Amna Md Noor. (2019). Kesan Keterlibatan Belia Dalam Aktiviti Gay di Kuala Lumpur. Malaysian Journal of Youth Studies. 2, 93-106.

Berita Harian. (2018). Bilangan gay, transgender semakin meningkat.

Beren, M. (2013). Gay and lesbian families in the early childhood clasroom: Evaluation of an online professional development course. Learning Landscapes, 7(1), 61-79.

Cass, V. (1996). Sexual orientation identity formation: A Western phenomenon.

Coleman, J. (1995). Teenagers and sexuality. Headway Hodder \& Stoughton: London.

Fadzilah Abdullah \& Noremy Md Akhir. (2019). LGBT dalam Kalangan Mahasiswa di Institusi Pengajian Tinggi Awam. Jurnal Wacana Sarjana, 1-11.

Fontanesi, L., Baiocco, R., Ioverno, S., Santamaria, F., Marasco, B., Baumgartner, E., Willoughby, B \& Laghi, F. (2014). Negative Parental Responses to Coming Out and Family Functioning in a Sample of Lesbian and Gay Young Adults. Journal of Child and Family Studies. 1-11. https://doi.org/10.1007/s10826-014-9954-z.

Global AIDS Response Progress Report (2016). Ministry of Health. Kuala Lumpur, Malaysia. 
Gullotta, T.P., Adams G.R., Markstrom, C.A. (2000). The Adolescent Experience, fourth edition, U.S.A., Academic Press.

Hafeez, H., Zeshan, M., Tahir, M. A., Jahan, N., \& Naveed, S. (2017). Health Care Disparities Among Lesbian, Gay, Bisexual, and Transgender Youth: A Literature Review. Cureus, 9(4), e1184. https://doi.org/10.7759/cureus.1184.

Hall, R. (2005). The well of loneliness. Wordsworth Editions.

Hassan, Amran \& Amat, Salleh. (2015). Kefahaman terhadap aspek pendefinisian dan ciri utama golongan homoseksual. The Social Science Journal, 10(2), 16-28.

Hegna, K. \& Wichstrøm, L. (2007). Suicide Attempts among Norwegian Gay, Lesbian and Bisexual Youths General and Specific Risk Factors. Acta Sociologica, 50. 21-37.

Johnson, M.O., Carrico, A.W., Chesney, M.A., Morin, S.F. (2008) Internalized heterosexism among HIV-positive, gay-identified men: implications for HIV prevention and care. $J$ Consult Clin Psychol, 76(5), 829-39.

Judge, C. C. (2015). Thrown Away for Being Gay: The Abandonment of LGBT Youth and Their Lack of Legal Recourse. Indiana Journal of Law and Social Equality, 3(2), 5. Doi: https://www.repository.law.indiana.edu/ijlse/vol3/iss2/5

Kamal Azmi Abd. Rahman, Mastura Md. Nizam \& Ain Balkis Mohd Azam. (2015). Profil

Masyarakat Melayu Malaysia di Media Sosial yang Mempromosikan LGBT. Isu-Isu Semasa Media dan Dakwah. Kuala Lumpur: Penerbit Universiti Malaya.

Mahfudzah, M. (2015). Lesbian, Gay, Biseksual dan Transgender: Perspektif Undang- undang Jenayah Syariah. Jurnal Undang-undang dan Masyarakat, 19, 29-36.

Mohamad Afandi Md Ismail \& Mohd Sabree Nasri. (2019). Gejala Lgbt Di Malaysia: Isu Dan Cadangan Penyelesaian. Journal of Law \& Governance, 2(1), 51-65.

Nina Farzuin Md Sharom (2019). Amalan LGBT tidak akan diterima di negara ini:

Mujahid. Berita Harian Online. Dicapai pada 1 April 2021 daripada https://www.sinarharian.com.my/article/17182/BERITA/Nasional/Amalan-LGBT-tidak-akanditerima-di-negara-ini-Mujahid

Proctor, C. D., Groze, V. K. (1994). Risk factors for suicide among gay, lesbian, and bisexual youths. Social Work Journal, 39(5), 504-513.

Rahman, Q., \& Wilson, G. D. 2003. "Born Gay? The Psychobiology of Human Sexual Orientation". Personality and Individual Differences, 34(8): p. 1337-1382. doi:10.1016/S01918869(02)00140-X.

Rezki Perdani Sawai, Noorhawaney Yahaya \& Syaidatun Nazirah Abu Zahrin. (2019) Homoseksualiti: Teori, Rawatan dan Pencegahan. Penerbit USIM.

Roseliza Murni Ab. Rahman (2003). Kecelaruan Identiti Jantina: Perspektif Psikososial dan Biologi. Jurnal Psikologi dan Pembangunan Manusia, 19, 41-57.

Savin-Williams, R. C., \& Ream, G. L. (2007). "Prevalence and Stability of Sexual Orientation Components During Adolescence and Young Adulthood". Archives of Sexual Behavior, 36(3), 385-394.

Schneider, W., Körkel, J, \& Weinert, F. (1989). Domain-Specific Knowledge and Memory Performance: A Comparison of High- and Low-Aptitude Children. Journal of Educational Psychology, 81, 306-312. http://doi.org/81. 10.1037/0022-0663.81.3.306.

Sell, R. L. (1997). "Defining and Measuring Sexual Orientation: A Review". Archives of Sexual Behavior, 26(6), 643-658. http://doi.org/10.1023/A:1024528427013

Suriati Ghazali, Jabil Mapjabil, Azilah Mohamad Nor, Narimah Samat, Jas Laile Suzana Jaafar. (2012). Difusi Ruangan Budaya Transeksualisme dan Imaginasi Geografi Pelajar Lelaki Berpenampilan Silang di Universiti Tempatan Malaysia. Journal of Social Sciences and Humanities,7(1),252266.

Suriati, G., Jabil, M., \& Azila, M. N. (2009). Infrastruktur komuniti dan hubungannya dengan golongan transeksual di Institusi Pengajian Tinggi Awam Malaysia. Jurnal Kemanusiaan, Bil. 18.

Syarifah Rohaniah Syed Mahmood. (2011). Effeminacy Among Male University Students of Malaysia: What Are The Underlying Contributing Factors. Kertas Kerja Pembentangan di Seminar Kaunseling Kebangsaan Pelbagai Budaya di UNIMAS 2011.

Ulrichs, K.H. (1994). The Riddle of Man-Manly Love. Buffalo, New York: Prometheus Books. 
DOI: https://doi.org/10.47405/mjssh.v6i5.795

Weeden, C., Lester, J. A., \& Jarvis, N. (2016). Lesbians and Gay Men's Vacation Motivations, Perceptions, and Constraints: A Study of Cruise Vacation Choice. Journal of homosexuality, 63(8), 1068-1085. https://doi.org/10.1080/00918369.2016.1150045

Zuraidah, Che Zarrina \& Chang (2018). Transgenderisme di Malaysia: Pelan Bimbingan Kembali Kepada Fitrah. Afkar Journal, 20(2), 279-322 